\title{
Editorial - Negotiating Agrarian Futures in China: Capital, Collectives, and Communities
}

\section{Karita Kan and René Trappel}

\section{(2) OpenEdition \\ 1 Journals}

\section{Electronic version}

URL: https://journals.openedition.org/chinaperspectives/11604

DOI: 10.4000/chinaperspectives. 11604

ISSN: 1996-4617

\section{Publisher}

Centre d'étude français sur la Chine contemporaine

\section{Printed version}

Date of publication: 1 June 2021

Number of pages: 3-7

ISSN: 2070-3449

\section{Electronic reference}

Karita Kan and René Trappel, "Editorial - Negotiating Agrarian Futures in China: Capital, Collectives, and Communities", China Perspectives [Online], 2021/2 | 2021, Online since 01 June 2021, connection on 17 November 2022. URL: http://journals.openedition.org/chinaperspectives/11604 ; DOI: https:// doi.org/10.4000/chinaperspectives. 11604 


\title{
Negotiating Agrarian Futures in China: Capital, Collectives, and Communities
}

\author{
KARITA KAN AND RENÉ TRAPPEL
}

$\mathrm{T}$ he globalisation of agricultural production and food systems has brought fundamental changes to agrarian economies around the world. While providing cheap and plentiful food for consumers and connecting rural communities to global circuits of production and distribution, the rise of corporate capital and industrialised production in agri-food politics have increasingly come under challenge for subsuming local development needs and environmental sustainability to marketoriented agendas (Borras 2010; Burnett and Murphy 2014). The advent of industrialised farming has been criticised for advancing capital at the expense of smallholders, as seen in the exploitation of farm labour, displacement of rural communities, and erosion of grassroots land control (Moyo and Yeros 2005; McMichael 2007). These emergent issues have triggered a search, similarly global in nature, by scholars, policymakers, and producers for alternative forms of agricultural production and rural development. At the same time, opposing trends to further expand the role of profit-oriented agriculture continue in many parts of the world.

As a globalising economy undergoing market reforms, with decades of preceding experience in agricultural collectivisation under state socialism, China presents a unique and significant case for comparative research into pathways of agrarian transition (Byres 1996). In a matter of decades, the country has experienced important structural changes in its agricultural sector. In the mid-1950s, the collectivisation movement reorganised rural economies through centralising production and distribution under the three-tier system of people's communes (renmin gongshe 人民公社), production brigades (shengchan dadui 生產大隊), and production teams (shengchan dui 生產隊) (Oi 1989). Rural communes were disbanded again in the 1980s, as the government introduced sweeping reforms to de-collectivise agriculture. Under the household responsibility system (jiating lianchan chengbao zhi 家庭聯產承包制), rural residents were contracted farmland to engage in household-based production, and could sell their produce in the market upon meeting state procurement quotas. These market-oriented reforms re-created traditional peasant farming practices and culture in the Chinese countryside (Kipnis 1995), and notably took place within an inherited framework of collective property rights. Unlike other post-socialist economies where land and other means of production were extensively privatised (Verdery 2003), the Chinese government continues to retain socialist property institutions while pursuing the modernisation of agriculture and the countryside at large (Putterman 1995; Kan 2016; Trappel 2016). This distinct pathway of agrarian development in China enables the possibility of "devising new analytical categories of agrarian transitions" (Zhang, Oya, and Ye 2015: 311). Bernstein (2015: 454) even suggested that the structural transformation of the Chinese countryside constitutes a significant case "from which future trajectories alternative to Western paths of development can be derived."

Into the third decade of the twenty-first century, agriculture in China is again experiencing widespread restructuring. On the one hand, the leadership's unambiguous promotion of agricultural modernisation has contributed to the scaling up of agriculture and the increased takeover of production activities by organised capital in the form of agri-businesses and commercial operators. Scholars have observed the rise of "agrarian capitalism" in China, where the means of production is increasingly subsumed under corporate control, and once-independent producers start to sell their labour for subsistence or leave agriculture altogether (Zhang and Donaldson 2008; Yan and Chen 2015). On the other hand, paradoxically, the new role of the market and the reduced influence of agents of the state on production have opened up space for experimentation in alternative models of economic organisation that go beyond for-profit agriculture. In particular, value-based communities trying to address growing concerns over food safety and rural sustainability have flourished (Si, Schumilas, and Scott 2015; Ku and Kan 2020). In their activities they often link together ideas to support smallholder farming, to create fair relationships between producers and consumers, and to promote organic and sustainable food production. Some of these community-based initiatives have even built on new interpretations of socialist institutions and legacies, as villages have re-introduced collectivism in agricultural production and resource management (Yan, Ku, and Xu 2020).

This special issue brings together contributions on the topic of agrarian futures in China. Drawing on case studies in Gansu, Guangxi, Guangdong, and Yunnan Provinces, the four papers in the collection present original and regionally diverse research that shares a common interest in exploring the dynamics of agrarian change in contemporary China. The authors respectively examine the role of and interaction between capital, collectives, and communities in rural China against the background of socialist legacies and capitalist transformation.

Based on intensive fieldwork at their selected research site, all four papers in the special issue shed light on the politics and power relations 
underlying and structuring the particular developmental initiatives studied. Exploring the politics of agrarian modernisation in China, René Trappel investigates how the active fostering of a new agrarian elite namely dragon head enterprises, family farms, and specialised households - by the Chinese Party-state has contributed to the marginalisation of small producers in Gansu. Turning to community-based initiatives and alternative food networks, the papers by Jean Tassin and Daren Shichi Leung reveal how seemingly bottom-up approaches to agricultural production and distribution are similarly beset by power dynamics and inequalities. Their papers highlight the unequal relations between farmers who grow and produce the food, and intermediary agents who have taken up the roles of marketing food products and certifying their quality, as well as attempts to rethink these relationships. Also exploring the micropolitics of rural development but in the context of a village that has recollectivised its resources, the paper by Xu Siyuan offers insights into how state-society interactions and intra-community dynamics shape resource management and economic practices in a forestry community.

In the remaining sections of this editorial, we highlight the key themes and findings of this special issue.

\section{Capitalist transformation in rural China}

Since the 2000s, the Chinese leadership has actively pursued an agenda of modernising agriculture, which involved scaling up, mechanising, and commercialising production, allocating the means of production such as land to the most efficient users, and encouraging specialisation in high value-added products. The emerging consensus among policymakers was that modernisation would bolster the efficiency and quality of agricultural production, helping to raise farmers' earnings and bridging the rural-urban income gap on the one hand, while facilitating the growth of internationally competitive agriculture on the other (Huang 2011; Trappel 2016).

The modernisation approach has defined recent structural reforms in China's agricultural sector. To begin with, the government has actively nurtured the rise of "new-type agricultural operators" (xinxing nongye jingying zhuti 新型農業經營主體) such as dragon head enterprises (longtou qiye 龍頭企業) (domestic agribusiness firms supported by the state to play a leading role in advancing agricultural industrialisation), specialised households (zhuanye dahu 專業大戶), family farms (jiating nongchang 家庭農場) (despite its name, a commercial farming operation of a certain size), and farmers' cooperatives (nongmin hezuoshe 農民 合作社). These have been promoted as the most suitable subjects for advancing economies of scale and professionalisation in agricultural production. In the government's vision, these new operators are to gradually incorporate and replace "small-scale producers" (xiaoguimo jingyinghu 小規模經營戶), which are deemed to be too fragmented (fensan 分散) and inefficient.

One of the latest policy documents on agricultural modernisation was released by the Ministry of Agriculture and Rural Affairs in March 2020. Entitled "Plan for the High-quality Development of New-type Agricultural Operators and Service Operators (2020-2022)," the document spelled out specific targets for the development of family farms and farmer's cooperatives. ${ }^{1}$ The number of family farms is to increase from 600,000 as of the end of 2018 to one million by 2022; meanwhile, farmers' cooperatives are expected to cover over $80 \%$ of farming households on a county basis. The document also calls for strengthening the agricultural services industry through the active fostering of organisations that specialise in the provision of services to farmers (nongye shehuihua fuwu zuzhi 農業社會化服務組織). These services include, for example, farm management services, the use of green technology, and the provision of specialised machinery for planting, harvesting, and other tasks. The Chinese government has given particular emphasis to the contracting of agricultural production (nongye shengchan tuoguan 農業生產托管) namely the hiring of service companies by rural households or new-type agricultural operators to take over part or all of the production process. ${ }^{2}$ Outsourcing to service operators is seen as a way for landholders, particularly small-scale producers, to solve the problems of being unable to farm the land (zhong bu liao di 種不了地) or lacking the ability to farm the land well (zhong bu hao di 種不好地). According to official figures, there are now 900,000 operators nationwide providing agricultural services to 7 million rural households. ${ }^{3}$ Their proliferation could further pave the way for the transfer of farming operations from small producers to commercial entities.

Parallel to the fostering of new agricultural and service operators is the reform of rural land rights, which has contributed to the expansion of rural land markets. In general, collective rural land must first be expropriated by the state before its use rights can be altered and sold in the conveyance market. Reforms in "land transfer" (tudi liuzhuan 土地 流轉) have introduced new market mechanisms for rural collectives and households to transfer their collective land usage rights to external parties (Trappel 2016; Kan 2021). For example, recently a tripartite rights system has been put in place to further clarify how collectives and households can transfer land use rights on farmland to commercial operators while respectively retaining ownership and contract rights. The main purpose of these reforms and the emerging land market seems to facilitate the consolidation of land in the hands of large-scale agricultural operators and new corporate actors such as tourism and hospitality companies (Trappel 2016; Andreas and Zhan 2016; Kan 2021).

How have these structural changes in Chinese agriculture affected the prospects of different farming operations on the ground? Drawing on fieldwork and interviews in Gansu Province, the first paper in this special issue by Trappel argues that the Party-state's fostering of the new agrarian elite has contributed to the creation of a "tilted playing field" at the expense of ordinary smallholders. In providing selective support to those agents of development it favoured - namely dragon heads and cooperatives - the Party-state has facilitated their growth and domination while subjecting small- and medium-sized producers to indirect displacement through market pressure and intensified competition. Trappel further observes how the mobilisational role (daidong 帶動) assigned to the new agrarian elite has in fact played out as the

1. “新型農業經營主體和服務主體高質量發展規劃 (2020-2022年)” (Xinxing nongye jingying zhuti he fuwu zhuti gao zhiliang fazhan guihua (2020-2022 nian), Plan for the High-quality Development of New-type Agricultural Operators and Service Operators (2020-2022)), Ministry of Agriculture and Rural Affairs (農業農村部), 3 March 2020, http://www.gov.cn/zhengce/ zhengceku/2020-03/24/content_5494794.htm (accessed on 20 April 2021).

2. For further details see “農業部辦公廳關於大力推進農業生產托管的指導意見” (Nongyebu bangongting guanyu dali tuijin nongye shengchan tuoguan de zhidao yijian, Guiding Opinions on Promoting Agricultural Production Trusteeship), Ministry of Agriculture and Rural Affairs (農業農 村部), 14 November 2017, http://www.hnyx.gov.cn/c6291/20180116/i617876.html (accessed on 25 May 2021).

3. “農業社會化服務組織年底預計超90萬個” (Nongye shehuihua fuwu zuzhi niandi yuji chao 90 wan ge, Agricultural Service Organisations are Expected to Exceed 900,000 by the End of the Year), Ministry of Agriculture and Rural Affairs (農業農村部), 18 December 2020, http://www.moa.gov. cn/ztzl/nyncfzcj/202012/t20201218_6359099.htm (accessed on 20 April 2021). 
takeover of small-scale farming operations by commercial establishments, with cooperatives being used as vehicles of vertical integration. These observations in Gansu provide rich empirical data for pondering how the replacement of smallholders by new agricultural subjects might affect the future of farming in China.

\section{The promises and politics of community initiatives}

While agricultural modernisation is placed front and centre in rural reforms by the policy elite, China has also been the site of experimentation in alternative models and approaches to development. Emerging in the first decade of the 2000s, a pro-peasant academic movement has been studied in the literature as the New Rural Reconstruction (NRR) movement (Yan and Chen 2013; Day 2013). Wen Tiejun, the movement's intellectual leader, contributed to the articulation of the "three rural problems" (sannong wenti 三農問題) and advocated the organisation of peasants into "comprehensive rural cooperatives" that integrated not only production processes but also social and cultural activities (Day and Schneider 2018). Another facet of agrarian activism, emerging in part in response to the proliferation of food safety issues, was the rise of alternative food networks that feature organic farming, community-supported agriculture, and partnerships between rural producers and affluent urban consumers (Si, Schumilas, and Scott 2015; $\mathrm{Ku}$ and Kan 2020). Initiatives in alternative food and farming practices have invigorated discourses in food sovereignty (shiwu zhuquan 食物 主權), as evidenced in the establishment of the People's Food Sovereignty Network in 2013 by researchers, students, and civil activists based in Mainland China, Hong Kong, and Taiwan (Ku and Kan 2020).

The different forms of rural and urban activism point to the possibility of alternative development trajectories. For example, scholars associated with the NRR movement view the proliferation of cooperatives as an opportunity to support smallholder farming through community-based practices (Yan, Ku, and Xu 2020). Cooperatives are seen as a countervailing force to agribusinesses, and community cooperation in public goods provision is viewed as a viable means to address the disintegration of rural societies (He 2007). Their envisioned cooperatives, however, differ considerably from the ones currently being created in the Chinese countryside at a rapid pace (Hu et al. 2017).

As the second and third papers in this special issue by Tassin and Leung reveal, it is important to go beyond frameworks of activism and peasant empowerment to examine how these initiatives might themselves reproduce difference and perpetuate inequalities. Tassin's paper focuses on the role that "returned youth" (fanxiang qingnian 返鄉青年) have played in China's alternative food markets. In recent years, state policies have encouraged the young and educated workforce that has left rural areas for urban jobs to go back to their hometowns to set up enterprises and create employment opportunities in the agricultural sector. According to Tassin, this has given rise to a new cohort of "peasant entrepreneurs" who, from the perspective of peasant empowerment, occupy an ambivalent position at the interface of small-scale, household-based farming and capitalised food markets. Making use of their cultural capital and technological skills, the entrepreneurs have assisted in the marketing of farm produce as high-quality organic food and provided an organisational platform for smallholders that help prevent "more intrusive forms of agrarian change," such as land transfer to agribusinesses. However, as managers and employers of migrant labour, these entrepreneurs have at the same time reproduced forms of domination and paternalism on the farms.

The role of intermediaries is similarly spotlighted in Leung's paper on community-supported agriculture in southern China. Distrust in conventional food labelling has contributed to the emergence of voluntary, trust-based mechanisms of food inspection such as the "Participatory Guarantee System," a third-party certification mechanism where intermediary organisations publish reports on food quality and safety. While these "participatory" practices are often hailed as a kind of bottom-up food activism, Leung demonstrates how they can in fact amount to a form of "social surveillance" where intermediary platforms wield enormous power in determining what constitutes "ethical" food and in sanctioning producers deemed to have violated these standards. Through the study of a food network based in Guangzhou, Leung proposes an "ethics of conviviality" as a way forward, envisioning the transformation of the relationship between intermediaries and producers from "buyers and suppliers" to "companions and carers." His paper thereby outlines a pathway for rethinking the politics of food from a relational perspective.

\section{Whither the collective economy?}

The final paper in this special issue considers the role and prospect of the collective economy (jiti jingji 集體經濟) in contemporary rural China. Unlike other former socialist states, China did not experience extensive privatisation of rural resources following de-collectivisation. Rather, socialist property institutions have been preserved, and rural collective organisations continue to exercise ownership rights over land and property. In peri-urban areas where large-scale land expropriations have taken place, many villages have re-collectivised land management and established shareholding corporations to profit from joint property development with local governments and real estate companies (Po 2008; Tang 2015; Kan 2019). In recent years, the strengthening of collective economies has gained ground in rural areas as well. The government has encouraged the development of rural collective economies in its Document No. 1 released in 2014; and the role of collective economies has also been emphasised in the Rural Revitalisation (xiangcun zhenxing 鄉村振興) campaign. Yet, there is again considerable need to scrutinise the meaning of this term in rural practice.

Amongst scholars and activists in China, there has been support for reinvigorating a particular understanding of collective economy. In 2016, the People's Food Sovereignty Network supported an open letter drafted by 18 rural cadres on strengthening rural collectives (Yan, $\mathrm{Ku}$, and $\mathrm{Xu}$ 2020). It is argued that reform-era policies have undermined villagers' collective rights to the autonomous management of resources, and that the consolidation of collective ownership is foundational to ecological protection and rural sustainability. While the group does not view all collective economies as embodying alternative practices, it is engaged in researching how rural collectives and cooperatives could become practice grounds for food sovereignty and ecological collectivism (ibid.). This call is in contrast to opposing political and economic trends of using collectivism to jump-start the expansion of entrepreneurial farming, for example through the forced pooling of collective land as described by Trappel in this issue.

The paper by Xu explores practices of village-level collectivism in the mountainous areas of Yunnan Province. The case study focuses 
on a forestry community where the village leadership has sought to retain collective management rights over forest resources despite pressures from both the government and local villagers to distribute resources to households. The paper on the one hand provides evidence for how recollectivisation could bring material benefits to the village community. For example, the sale of timber grown in the collective forest furnished the collective with income to improve elderly care and provide scholarships for students. On the other hand, the paper also reveals the challenges faced by collective economies. In the bid to capitalise on collective forest resources through tourism-led development, the village was forced into heavy debt as a result of external borrowing, which opened the door to subsequent government intervention. Rather than supporting autonomous self-management and consolidating villagers' rights, the community was led down a path of growing dependence on the state and external capital.

Together, the four papers in this special issue provide rich empirical materials for probing the different but linked dimensions of agrarian change in contemporary China. While it seems clearer than ever that the country is heading down the path of modernisation spearheaded by elite agricultural operators, the research presented in this collection also demonstrates diversity on the ground in terms of ownership form, level of state engagement, and local initiatives that promote different norms and values. While initiatives such as alternative food networks and collective resource management represent attempts to go beyond for-profit agriculture, they are not viewed as a panacea to the problems confronting agriculture in China. Rather, the findings reaffirm the importance of interrogating the meaning of "alternative" food and farming practices and of observing how these practices could deepen rural differentiation and entrench inequalities both within and between the rural and urban spheres (Huang 2011; Day and Schneider 2018). Research on agrarian futures in China can further consider not only the potential but also the limits, contradictions, and opposing trends that could confront alternative pathways of development.

\section{Acknowledgements}

We would like to thank Éric Florence, Pierre Miège, Judith Audin, and the editorial team for their valuable advice and helpful guidance throughout the different stages of the publication process. The organisation of the special issue is fully supported by a grant from the Research Grants Council of the Hong Kong Special Administrative Region, China (Project No. PolyU 15601818). We thank all contributors and reviewers for making this special issue possible.

I Karita Kan is Assistant Professor at the Department of Applied Social Sciences, Hong Kong Polytechnic University. She researches rural transformation in post-socialist China, with a focus on urbanisation, the politics of land and property, and grassroots governance. Department of Applied Social Sciences, Hong Kong Polytechnic University, Hung Hom, Hong Kong SAR (karita.kan@polyu.edu.hk).

I René Trappel is a comparative political scientist and Senior Lecturer at the Institute of Chinese Studies at the University of Freiburg. His current research focuses on agrarian change, urbanisation, local governance, and state-society relations in China. Institute of Chinese Studies, University of Freiburg, Freiburg, Germany (rene.trappel@ sinologie.uni-freiburg.de).

\section{References}

ANDREAS, Joel, and Shaohua ZHAN. 2016. "Hukou and Land: Market Reform and Rural Displacement in China." Journal of Peasant Studies 43(4): 798-827.

BERNSTEIN, Henry. 2015. "Some Reflections on Agrarian Change in China." Journal of Agrarian Change 15(3): 454-77.

BORRAS, Saturnino M. 2010. "The Politics of Transnational Agrarian Movements." Development and Change 41(5): 771-803.

BURNETT, Kim, and Sophia MURPHY. 2014. "What Place for International Trade in Food Sovereignty?" Journal of Peasant Studies 41(6): 1065-84.

BYRES, Terence J. 1996. Capitalism From Above and Capitalism From Below. New York and London: Palgrave Macmillan.

DAY, Alexander F. 2013. The Peasant in Postsocialist China: History, Politics, and Capitalism. Cambridge: Cambridge University Press.

DAY, Alexander F., and Mindi SCHNEIDER. 2018. "The End of Alternatives? Capitalist Transformation, Rural Activism and the Politics of Possibility in China." Journal of Peasant Studies 45(7): 1221-46.
HE, Xuefeng. 2007. "New Rural Construction and the Chinese Path." Chinese Anthropology and Sociology 39(4): 26-38.

HU, Zhanping, Qian Forrest ZHANG, and John A. DONALDSON. 2017. "Farmers' Cooperatives in China: A Typology of Fraud and Failure." The China Journal 78(1): 1-24.

HUANG, Philip. 2011. "New-age Small Farms and their Vertical Integration: Agribusiness or Co-ops?" Modern China 37(2): 107-34.

KAN, Karita. 2016. "The Transformation of the Village Collective in Urbanising China: A Historical Institutional Analysis." Journal of Rural Studies 47: 588-600.

KAN, Karita. 2019. "A Weapon of the Weak? Shareholding, Property Rights and Villager Empowerment in China." The China Quarterly 237: 131-52.

KAN, Karita. 2021. "Creating Land Markets for Rural Revitalization: Land Transfer, Property Rights and Gentrification in China." Journal of Rural Studies 81: 68-77.

KIPNIS, Andrew B. 1995. "Within and Against Peasantness: Backwardness and Filiality in Rural China." Comparative Studies in Society and History 37(1): 110-35. 
KU, Hok Bun, and Karita KAN. 2020. "Social Work and Sustainable Rural Development: The Practice of Social Economy in China." International Journal of Social Welfare 29(4): 346-55.

MCMICHAEL, Philip. 2007. "Feeding the World: Agriculture, Development and Ecology." Socialist Register 43: 170-94.

MOYO, Sam, and Paris YEROS (eds.). 2005. Reclaiming the Land: The Resurgence of Rural Movements in Africa, Asia and Latin America. London and New York: Zed Books.

OI, Jean C. 1989. State and Peasant in Contemporary China: The Political Economy of Village Government. Berkeley: University of California Press.

PO, Lanchih. 2008. "Redefining Rural Collectives in China: Land Conversion and the Emergence of Rural Shareholding Co-operatives." Urban Studies 45(8): 1603-23.

PUTTERMAN, Louis. 1995. "The Role of Ownership and Property Rights in China's Economic Transition." The China Quarterly 144: 1047-64.

SI, Zhenzhong, Theresa SCHUMILAS, and Steffanie SCOTT. 2015. "Characterizing Alternative Food Networks in China." Agriculture and Human Values 32(2): 299-313.
TANG, Beibei. 2015. "'Not Rural but Not Urban': Community Governance in China's Urban Villages." The China Quarterly 223: 72444.

TRAPPEL, René. 2016. China's Agrarian Transition: Peasants, Property, and Politics. Lanham: Lexington Books.

VERDERY, Katherine. 2018. The Vanishing Hectare: Property and Value in Postsocialist Transylvania. Ithaca: Cornell University Press.

YAN, Hairong, and Yiyuan CHEN. 2015. "Agrarian Capitalization Without Capitalism? Capitalist Dynamics from Above and Below in China." Journal of Agrarian Change 15(3): 366-91.

YAN, Hairong, Hok Bun KU, and Siyuan XU. 2020. "Rural Revitalization, Scholars, and the Dynamics of the Collective Future in China." Journal of Peasant Studies. https://doi.org/10.1080/03066150.2019.1694911.

ZHANG, Qian Forrest, and John A. DONALDSON. 2008. "The Rise of Agrarian Capitalism with Chinese Characteristics: Agricultural Modernization, Agribusiness and Collective Land Rights." The China Journal 60: 25-47.

ZHANG, Qian Forrest, Carlos OYA, and jingzhong YE. 2015. "Bringing Agriculture Back In: The Central Place of Agrarian Change in Rural China Studies." Journal of Agrarian Change 15(3): 299-313. 